\title{
National Constitution: A Foundation for Exemplary Leadership and Development in African Transition Economies
}

\section{Chukwuemeka Nnadi*}

Department of Management, Faculty of Business Administration, University of Nigeria, Enugu Campus, Enugu State, Nigeria

"Corresponding author: Chukwuemeka Nnadi, Department of Management, Faculty of Business Administration, University of Nigeria, Enugu Campus, Enugu State, Nigeria, Tel: 08066707488; E-mail: chukwuemeka.nnadi@unn.edu.ng

Received date: August 11, 2014; Accepted date: October 06, 2014; Published date: October 16, 2014

Copyright: @ 2014 Nnadi C. This is an open-access article distributed under the terms of the Creative Commons Attribution License, which permits unrestricted use, distribution, and reproduction in any medium, provided the original author and source are credited.

\begin{abstract}
National constitution: A foundation for exemplary leadership and development in African transition economies. The study sets out to accomplish these objectives to: investigate the causes of the low speed accumulation of human capital; ascertain why Nigerian leaders make disastrous choices resulting in failing health and educational system as well as examine why Military Decree No 24 CFRN (1999) continues to serve as CFRNA in a democratic dispensation. The study used a secondary instrument for data collection from relevant journals, magazines, books and internet. The gap in literature shows that most African States are still chained to Military Decrees as their respective constitutions. The supreme court over rules itself, consequently any sovereign, military or civilian, can overrule itself. The findings are that: the military personnel attained minimal educational level, consequently, its decree No 24 CFRN (1999) perpetuates illiteracy; and the military rule left in its wake, a sad legacy of human rights violations, stunted national growth a corporatism and static state, increased corruption and posing the greatest threat to democracy and national integration. Based on these findings, the recommendations are that: Decree No 24 CFRNA is being stretched beyond its usefulness: This paper advocates for a transition period for the formulation of a progressive democratic constitution and the raising of the educational level to a good first Degree from a recognized university for membership of the National Assembly. The conclusion is that Decree 24 CFRNA (1999) and its - up to at least school certificate level turns retired wealthy military generals and officers as unprepared political leaders and actors politically. The Nigerian culture of illiteracy is the exact symbol of its laws.
\end{abstract}

Keywords: Military-decree; Illteracy; Corruption; Good-degree; National Assembly; Democratic-constitution; Educated-population; National-development

\section{Introduction}

Onah [1] states that the developing economies only profit from globalization in the form of increased foreign trade, foreign direct investment and international borrowing. These economics seek financial assistance from the International Monetary Fund (IMF) and the World Bank (WB). These financial institutions apply a neo-liberal economic ideology or agenda as pre-conditions to receiving the loan. Also, circumstances compel developing economics to concentrate on similar cash crops and commodities [2]. Most of these economies rely on a narrow range of primary commodity exports for their foreign exchange earning. The world prices for these commodities are often unstable leading to considerable functions in the income of the exporting states [3]. The scenario is like a huge price war; their resources then become cheaper favouring consumers in the west.

The IMF was originally envisioned to promote steady growth and full employment by offering unconditional loans to economies in crisis and establishing mechanisms to stabilize exchange rate and facilitate currency exchange. Much of this vision however, was never born. Instead, pressured by United States representatives, the IMF took to offering loans based on strict conditions, later to be known as structural adjustment or austerity measures dictated largely by the most powerful nations. The World Bank (The International Bank for Reconstruction and Development) was created to fund the rebuilding of infrastructure in nations ravaged by world war two. Its vision too, however, soon changed.

The world system theory according to Wallerstein [4] states that the modern world-system originated around 1500 in parts of Western Europe. A long-term crisis of feudalism gave way to technological innovation and the rise of market institutions. Advances in production and incentives for long-distance trade stimulated Europeans to reach other parts of the globe. Superior military strength and means of transportation enabled them to establish economic ties with other regions that favoured the accumulation of wealth in the European core. Capital-intensive production was reserved for core countries while peripheral areas provided low-skill labour and raw materials. This is why Philip Emeagwali, the famed super computer pioneer in his key not address in University of Edmonton Canada on September 23, 2006 asked the question: Where is Africa going wrong? In his considered view, Africa including Nigeria, was missing the Mark as well as the thrust in the application of its potentials for progress and poverty-alleviation by relying in its ability to pick minerals from the ground or seek debt relief and foreign assistance: He blamed Africa for investing more on things than on information and more on the military than on education. He remarked that knowledge and ideas' are the engines that drive economic growth and industrial revolution.

Some of the causes for the occurrence of Industrial Revolution in Britain are: The stable political situation in Britain from around 1688 and the British society's greater receptiveness to change [5]; the availability of key resources it possessed. It had a dense population for its small geographical size; the greater liberalization of trade from a 
Page 2 of 9

large merchant base; the presence of an entrepreneurial class which believed in progress, technology and hard work and others.

Governments of advanced market economies orient their policies and programmers towards fostering entrepreneurship. According to the experience of the European Commission, some of the most dynamic SMEs use business services to perform functions that cannot be undertaken in house.

The UNECE sets a high value on the development of SMEs both in advanced and in transition and emerging market economies. In its work, it stressed that Governments can and must help in creating an enabling environment for SMEs so that they can more easily cope with the ever-increasing challenges [6].

The prosperity of Britain or any part of the world like United States of America is a result of the relationship between its enlightened, technological-developed and committed citizens. Enekwe [7] shows that the poverty of any part of the world particularly Nigeria is a result of the relationship between its inhabitants:

"The citizens of any nation can determine whether or not they want to be poor. This they can do through the way they manage their resources and their affairs. If they are able to manage and develop what they have, like Britain, they are rich, if not, they are poor, no matter the quantity of minerals in the ground, no matter the fertility of their soil. It is in this sense that we can conclude that Nigeria is a poor country $[8,9]$.

\section{Influence/impact of law}

The British 'common law' comprises the rules finely attuned to the needs of the society, a system of judge-made rules that were common to all the people in the land. Every person came under the Rule of Law.

"This Common Law... makes itself up as it goes along; it sets precedents but they are never unalterable, because they are derived ultimately, not from a book of rules, but from a judge's intuitive feeling for equity and fair play-from a man rather than a machine... Common Law assumes a freely developing pattern which is nevertheless consistent with itself; like the development of a living language" [10].

Nigerian constitution is a code law which assumes a pattern laid down once and for all [8]. The constitutions of some African economies or states will be analyzed to ascertain impact on governance and over-all outcome in global economic standing.

\section{Statement of problem}

The low speed accumulation of human capital especially in science and technology causes previous peer nations to leave developing economics including Nigeria behind at the lower rungs of the global GDP economic ranking. The lag or crawling progress in tertiary education enrollment creates a competitiveness gap between the same previous peer nations and Nigeria. African leadership particularly Nigerian leadership has made disastrous choices that have trapped Nigeria's destiny in oil wells and created an indulgent elite class. Most Nigerians especially the poor continue to suffer the effects of the falling public health and education system as well as decrepit infrastructure and battered institutions.

\section{Objectives of the Study}

1. To investigate the causes of the low-speed accumulation of human capital especially in science and technology causing peer nations to leave African economies including Nigeria behind at the lower rungs of the global GDP economic ranking.

2. To find out the lag or crawling progress in tertiary education enrollment creating competitiveness gap between the same previous peer nations and Nigeria.

3. To find out why African leadership particularly Nigerian leadership made disastrous choices that have trapped Nigeria's destiny in oil wells and created indulgent elite class.

4. To examine why most Nigerians especially the poor continue to suffer the effects of the falling public health and education system as well as decrepit infrastructure and battered institutions

\section{Research questions}

1. To what extent does the low-speed accumulation of human capital especially in science and technology cause peer nations to outgrow African countries including Nigeria on the high rungs of the global GDP economic making?

2. How does the lag or crawling progress in tertiary education enrollment create a competitiveness gap between the same previous peer nations and Nigeria?

3. Why does African leadership particularly the Nigerian leadership make disastrous choices that trapped Nigeria's destiny in oil wells and created indulgent elite class?

4. Why do most Nigerians especially the poor continue to suffer the effects of the falling public health and education system as well as decrepit infrastructure and battered institutions?

\section{Review of Related Literature}

\section{Theoretical framework}

The theoretical framework is based on the theory of material and the theory of relative factor endowments. The two theories are complementary in that material is an endowment. Every situation or part of the globe has a unique material for the material prosperity of its people. The totalities of these situations or parts make up the globe. Enekwe [7] affirms that God so designed the world that it lacks nothing.

The theory of material brings management to the fore or focus. Management remains the basic and dominant institution as long as western civilization itself survives. It is not only grounded in the nature of the modern industrial system and in the needs of the modern business enterprise to which an industrial system must entrust its productive resources, both human and material. Management expresses the basic beliefs of modern Western Society. It expresses the belief in the possibility of controlling man's livelihood through systematic organization of economic resources. It expresses the belief that economic change can be made into the most powerful engine for human betterment and social justice. In other words it can turn an economy of scarcity into an Economy of Abundance. This theory of material is something new, distinctly modern, and distinctly Western [9]. The theory of relative factor endowments: David Ricardo's theory of comparative advantage suggests that opportunity costs should determine what a country will produce most efficiently and most profitably. However, his theory ignores the fact that different countries 
often have different opportunity costs. This issue was examined by two-Swedish economists, El, Heckscher and Bertil Ohlin, in what is called the theory of relative factor endowments. The theory attempts to explain the relationship between a country's factor endowments (e.g. land, labour, capital) and its comparative advantage in international trade. Specifically $\mathrm{H}-\mathrm{O}$ theory asset that a country will have comparative advantage in products and commodities in cases where production requires considerable resources that the country has in abundance. Such products would be exported, while the same country would import commodities that require substantial input of resources that are scarce in that country. In other words, countries can gain a competitive advantage in global trade by specializing in industries for which they have an abundance of input resources. As a result, differences in comparative advantage are based largely on differences in the structure of each country's economy.

Limitations: However the Hecksher-Ohlin theorem is based on at least two limiting assumptions. First, it assumes that the same amounts of capital and labour are required to produce a product in any country. This is obviously not always the case. Second, it assumes that available technology and skilled human capital are constant across nations ignoring the fact there are often different ways to make the same product. The more recent product life cycle model has attempted to resolve these contradictions.

\section{Product life cycle theory}

In the 1960s Raymond Vernon added to our understanding of international trade by pointing out that the comparative advantage that a nation or firm enjoys at one stage of a product's life cycle may disappear at another stage. This is called the product life cycle theory while the actual process by which this theory works is referred to as dynamic competitive advantage. Vernon identified three stages in the product life cycle of a typical product: new product stage, maturing product stage and standardized product stage.

New Product State: a firm introduces a new, innovative product because the product is new, it typically requires intensive research and developments, highly skilled labour and production capabilities that are near the initial targeted markets, usually rich or developed countries such as those of the United States, Japan or Western Europe. In this stage there is little or no international trade.

Mature Product State: demand for the product expands and the firm builds new factories both at home and abroad to serve the emerging international markets.

Standardized Product State: the market for the product stabilizes, the product becomes more of a commodity than a brand and pressures to lower costs accelerate. For this reason, production shifts to developing countries that can produce at lower costs.

\section{Implications of the theories}

The theory of material and the theory of relative factor endowments are appropriate to Nigerian situation. Nigeria has great endowments. It is endowed with abundant human and material resources. The country has an estimated land area of $923.773 \mathrm{~km} 2$, with varied vegetation and soil types that are suitable for a variety of agricultural purposes. It has large reserves of solid minerals including coal, columbine, lignite, tin, bitumen, topac, kaolinite, talc, marble, barite, gypsum and iron ore. The proven reserves of crude petroleum and natural gas are well over 27 billion barrels and 120 trillion standard cubic feet, respectively. The Federal Government of Nigeria prepared the record of the above material types or endowments. It went ahead to claim that "these vast resources are capable of forming a solid base for development. Unfortunately, it expressed a regret of obvious internal incapacity: 'Granted political stability, good governance and exemplary leadership, Nigeria has a high potential of becoming a great nations in this millennium' [10]. This is a sincere admission of clear incompetence.

For example, Britain was able to succeed in the industrial Revolution due to the availability of key resources it possessed. It had a dense population for its small geographical size. Enclosure of common land and the related agricultural revolution made a supply of this labour readily available... local supplies of coal, iron, lead, copper, tin limestone and water- power resulted in excellent conditions for the development and expansion of industry [5].

Also, the theory of relative factor endowments reveals incompetence in the realm of science and technology. Nigeria has low redemptory scientific and technological base. Unlike, Slovakia, Nigeria has unskilled unemployable labour, very poor infrastructure, high internal insecurity; electricity is more of a problem for small and medium-sized firms [11]. In comparison with other countries, firms in Nigeria face high indirect costs than firms in all other countries. By contrast Nigerian firms have similar indirect costs resulting from corruption and crime see Figure 1 and Table 1, Slovakia is an emerging automobile industry.

A large number of the cars driving down the busy streets of Berlin, Paris, Caphebagen and Rome may soon have something in common. They will be made in Slovakia. All these cars being made in a country of 5.4 million people will soon make Slovakia the biggest producer of cars in the world on a per capita basis [12]. In Nigeria's mining and quarrying (solid mineral) sector, infrastructure at mine sites deteriorated due to neglect. The country's manufacturing sector was compelled to depend on the importation of minerals that it has in abundance [10].

This paper uses Nigeria as a lead example with insight into some African countries like Ivory Coast, Uganda and others.

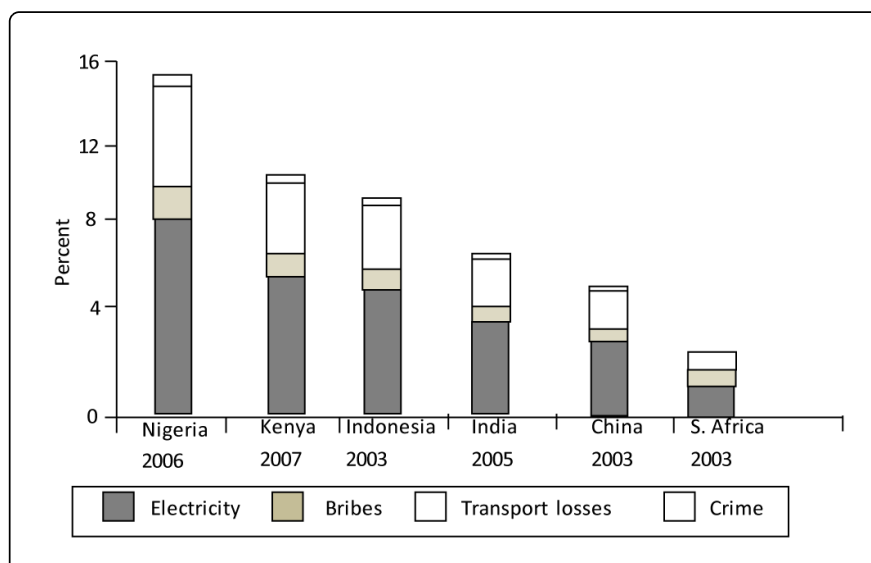

Figure 1: Indirect Costs-Manufacturing sector. Source: ICA survey. 


\begin{tabular}{|l|l|l|l|l|l|l|l|l|l|l|}
\hline Indirect cost as & \multicolumn{3}{|l|}{ Exporting zone } & \multicolumn{2}{l|}{ Firm size } & \multicolumn{3}{l|}{ Ownership } & \multicolumn{2}{l|}{ State } \\
\hline$\%$ sales & Total & Yes & No & Small & Med & Large & Foreign & Local & $\begin{array}{l}\text { More } \\
\text { industrialized }\end{array}$ & $\begin{array}{l}\text { Less } \\
\text { industrialized }\end{array}$ \\
\hline Electricity & 9.8 & 9.3 & 9.9 & 10.2 & 9.3 & 5.3 & 10.3 & 9.8 & 9.8 & 9.7 \\
\hline Bribes & 1.7 & 2.8 & 1.5 & 1.5 & 2.2 & 0.9 & 0.4 & 1.7 & 1.7 & 1.6 \\
\hline $\begin{array}{l}\text { Production lost } \\
\text { while in transit }\end{array}$ & 4.1 & 7.3 & 3.6 & 3.3 & 5.2 & 11.6 & 1.7 & 4.2 & 3.8 & 4.9 \\
\hline $\begin{array}{l}\text { Theft, robbery or } \\
\text { arson }\end{array}$ & 0.3 & 0.3 & 0.4 & 0.3 & 0.4 & 0.4 & 0.3 & 0.3 & 0.3 & 0.5 \\
\hline $\begin{array}{l}\text { Total indirect } \\
\text { costs }\end{array}$ & 15.9 & 19.7 & 15.3 & 15.3 & 17.2 & & & & & \\
\hline
\end{tabular}

Table 1: Indirect Costs-Manufacturing sector. Source: ICA survey.

\section{Nigerian leadership}

The trouble with Nigeria is simply and squarely a failure of leadership. There is nothing basically wrong with the Nigerian land or climate or water or air or anything else. The Nigerian problem is the unwillingness or inability of its leaders to rise to the responsibility and to the challenge of personal example which are the hallmarks of true leadership [13]. We squander our wealth like infants who have little sense of the value of things. But who are the 'we' in this piece. They are the ruling class who has determined the fortunes of this country since independence. The Nigerian elite class is not creative. It is not patriotic. It has its soul in London and New York, while its anus creates havoc in Lagos (and now Abuja). It steals the wealth of the nation and transforms it into nothing. By serving foreign interests our elite class has ensured that Nigerians will remain unable to manage their affairs in the future, thus perpetuating poverty despite the incredible richness of our hand Enekwe [7]. The comments of its leaders show lack of faith in the destiny of Nigeria. In 1947, Chief Obafemi A. Awolowo wrote: "Nigeria is not a nation. It is a mere geographical expression...Nigeria is merely a distinctive appellation to distinguish those who live within the boundaries of Nigeria from those who do not Awolowo.

Chief Awolowo is one the leading Nigerian Nationalist, then Premier of Western Region, Leader of the Action Group Party and was educated in Britain.

In 1948, a year later, the Late Prime Minister of Nigeria Sir Abubakar Tafawa Balewa was reported to have said in the legislative council that as quoted in James S. Coleman: "Nigeria unity is only a British intension. For the country...”. Sir Abubakar Tafawa Balewa was a primary classroom teacher, this upliftment to the highest political position was a British design as shown below:

"One example that I will give to illustrate the complexity of that moment of transition occurred at the very highest level of government. When Britain decided to hand over power to Nigeria, they also decided to change the governor general. They brought a new governor general from Sudan, Sir James Robertson to take the reins in Nigeria..." "It is now widely known that Sir James Robertson played an important role in overseeing the elections (or lack thereof) at independence, throwing his weight behind Abubakar Tafawa Balewa, who had been tipped to become Nigeria's first Prime Minister $[14,15]^{\prime \prime}$.

Leadership Drama: Chief Olusegun Obasanjo, now a civilian Head of State, announced the setting up of the Human Rights Violation Investigation Commission (HRVIC) headed by Retired Supreme Court, Justice Chukwudifu Oputa. The legal instrument that set up the commission was the statutory instrument Number of 18 of 1999 under the Tribunals Inquiry Act Cap 447 Laws of the Federation of Nigeria, 1990. The report of the commission was submitted on 28 May 2002. But unlike the South African-Truth and Reconciliation Commission Report which was made to take its place in the historical landscape of which future generations will try to make sense, searching for clues that lead... to a truth, the Nigerian Government is bent on burying its own document so that the present and future generations will get lost in the labyrinth of injustice [16].

\section{Military in governance in Nigeria}

The military regime abandoned its constitutional duty and set for itself the political task of ruling Nigeria through Decree No 24 [17] which ousted the then constitution of Nigeria.

\section{The Federal Military Government}

Hereby decrees as follows:-

1. There shall be for Nigeria a constitution which shall be as set out in the schedule to this Decree

2. The constitution set out in the schedule to this decrees shall come into force on 29th day of May 1999.

3. Wherever it may hereafter be necessary for the constitution to be printed it shall be lawful for the Federal Government printer to omit all parts of this Decree apart from the Schedule and the Constitution as so printed shall have the force of law notwithstanding the omission.

This decree may be cited as the Constitution of the Federal Republic of Nigeria (Promulgation) Decree 1999 [17]. 


\section{Comment}

There is no evidence of ratification by the civilian government. The additional of the word-'ACT' is not ratification. There is confusion as to its continuing validity. Its continuing validity is sustained by the military or retired wealthy military doubling as either military Heads of State of Nigeria or dominating the membership of the National Assembly.

One most disturbing factor is using 'Decree' which is the absolute personal opinion of a military Head of State to create Local Governments in Nigeria. This sharing is not based on any empirical evidence. For example Kano State has 45 Local Governments: Is Kano the most populated state in Nigeria. The military created states with a fiat but it makes difficult or almost impossible for civilian government to create states: Section 8 'An Act of the National Assembly for the purpose of creating a new State shall only be passed if -

a request, supported by at least two-thirds majority of members (representing the area demanding the creation of the new State) in each of the following, namely -

- The Senate and the House of Representatives,

- The House of Assembly in respect of the area, and

- The local government councils in respect of the area, is received by the National Assembly;

A proposal for the creation of the State is thereafter approved in a referendum by at least two-thirds majority of the people of the area where the demand for creation of the State originated;

The result of the referendum is then approved by simple majority of all the States of the Federation supported by a simple majority of members of the Houses of Assembly; and

The proposal is approved by a resolution passed by two-thirds majority of members of each House of the National Assembly.

This is again sustained by military Heads of State in succession handing over power through a mock arrangement of overthrow of the existing governments by: IBB, Sani Abacha, Abdusalami Abubakar in succession all three from the Far North. Two of them came from Niger State. The same Military Generals allocated Nigerian oil blocks to themselves and their relations, their in-laws and fronts. None of these Military Heads of State was a university graduate of a recognized institution or had good background in Economics for every political issue has an economic dimension [16].

The military regime in governance impacted negatively on human resource management or human capital development of Nigerian citizens and entrepreneurs. They issued decrees fraught with ouster clauses to whittle down the force of constitution and muzzle up intellectuals and idle civilians. For example: it used advanced technology in the form of a letter bomb to kill resourceful person(s) (HRVIC in [15]).

\section{Unprepared national leaders}

Civilian Presidents and Military Heads of State of Nigeria since 1960 have only political clout but they critically lack the standard of educational background or sound knowledge background to unravel the mystery of the national, international and global political and economic changes confronting Heads of State in the global setting. Nigeria got her first graduate Head of State in the person of Shehu Yar'Adua. Today Nigeria is lucky to have President Goodluck Ebele
Jonathan as the first Head of State with a Ph.D. others Tafawa Balewa, Generals Johnson Aguiyi-Ironsi, Yakubu Gowon, Murtala Mohammed, Olusegun Obasanjo (First time but through providence), President Shehu Shagari, Generals Mohammed Buhari, Ibrahim Babangida Sani Abacha, Abdusalami Abubaka, President Olusegun Obasanjo second time as an elected Civilian President. Now president Goodluck Ebele Jonathan formerly a Vice President to President Shehu Shagari and through providence became the President for the unexpired tenure of President Shehu Shagari. But now duly elected as President of Nigeria.

\section{Summary of review of related literature on governance of Nigeria}

Nigerian civil Heads of States ruled with limited knowledge. They relied heavily on political tactics and manovres to float in office. They use the power and authority of office of the Presidency to protect their weaknesses during their respective tenures thereby exposing the citizens of Nigeria to ignorance and pain causing them to detach themselves and doubt the intention of government public programmes. The Military Heads of State of Nigeria were schooled in handling five arms for the defence of the territorial boundaries of Nigeria in Land, Sea and air. Unfortunately, while in power they directed the guns on the people they are constitutionally set up to secure their lives and properties. In some cases, either by accidents or design, encounter with them by express of conflict view or any form of opposition, civilian lives of resourceful persons may be lost. The gap in literature is very obvious Africa including Nigeria missed the mark as well as the thrust in the application of its potential for progress and poverty alleviation by relying in its ability to pick minerals from the ground or seek debt relief and foreign assistance. They invested more on things than on information and mere on the military than on education. Knowledge and ideas which is the engine that derive economic growth are completely neglected. This gave competitiveness gap between then peer countries and Nigeria. For example while manufacturers as a percentages of total exports is about 40 percent in Indonesia, it is less than one percent in Nigeria, where Nigeria was in 1970 [18]. They cover this weakness using the law or constitutional provision enacted by themselves as legislative executive and judicial organs.

\section{What is law?}

Every government is the exact symbol of its people (writes historian Thomas Carlyle in Purver [18]). So it is with Law. The laws and legal system of a society reflect the values of its people but in Nigeria, the values of its elite class are the national values. Also the fairness of a nation's laws and the extent to which the legal system justly administers the laws is a measure of the enlightenment, humanity and degree of civilization of its people [18]. In Nigeria, the intent of the laws is not clear and the legal system is the manipulative tool of politicians. Nigerian laws and legal system are crude.

\section{Nigerian constitution CFRN 1999 Decree No 24 Now CFRNA (Act)}

Section 1-(1) emphasizes the supremacy of the 1999 CFRN. The constitution is supreme. What is supreme in Nigeria is politics or blind politics. 


\section{Chapter II}

The fundamental objectives and decreative principles of state policy:

In section 14:(8) it provides: "The composition of government of the Federation or any of its agencies and the conduct of its affairs shall be carried out in such a manner as to reflect the federal character of Nigeria and the need to promote national unity and also to command national loyalty, thereby ensuring that there shall be no predominance of person from few states or from a few ethnic or other in any of its agencies"

\section{Comment:}

African states have undergone drastic changes since independence. The most relevant change is the weakening of the political structures. Virtually all African states have had one form of military intervention or the other [19]. Those that survived the intervention quickly moved to various forms of personal rulership, dictatorship or ritualistic democracy. Secondly, elections have been forgotten in the wake of military rule. The military bureaucracy has imposed itself on the people. The 'will' of the military leader has become the will of the people. Thirdly, in very few cases where occasional elections are still held the entire exercise is reduced to mere ritual. In some extreme cases, the people are told exactly whom to elect. Whether, it is in Tanzania, Zambia, the Ivory coast, Senegal, Nigeria or Kenya, the people choose from the already chosen (Geranty Hyden and Colin Leys [20] (For Kenya and Tanzania) Bienen (194, for Kenya) Joel Samoff for Zambia, David Mulford for Zambia).

Composition of Government and its Agencies: The mistaken assumption is that the membership of both government and its agencies is a Nigerian citizen from 18 years and above (or tribal native member). For membership of the National Assembly... chapter V- the Legislature:

Section 64 subsection c- qualification for membership of National Assembly

Section 65(2)- A person shall be qualified for election under subsection I of this section if

- he has been educated up to at least school certificate level or its equivalent and

- he is a member of a political party and is sponsored by the party.

But an Agency Membership is from recruitment Gordon [21] clearly delineates between government or public (sector) administration and public management thus:

Public administration comprises all processes, organizations and individuals (the later acting in official positions and roles) associated with carrying out laws and other rules adopted or issued by legislatures, executives and courts; many activities (also) concerned with formulation of these rules, a field of academic study and professional training leading to public service careers at all level of governing.

And, Agency or public management which is a field of practice and study central to public administration, emphasizing internal operations of public agencies, focuses on managerial concerns related to control and direction, such as planning, organizational maintenance, information systems, personnel management and performance evaluation.
Mode of entry into Agencies: Through Recruitment: In agencies are the workers that make up the establishment or organization. The objectives and the organizational planning determine the duties (not political dividend), the scope and the level of individual jobs.

Recruitment is the process of assessing a job announcing the vacancy, arousing interest and stimulating people to apply (for selection).

Selection is the exercise of choosing for excellence (not representation on the basis of subjective factors) through the process of rejecting or matching of the applicants, first against the attributes which are expected to make for success on the job and secondly, matching of the candidate's one against the other until the appointable candidate are rank-ordered in order of relative suitability.

Placement is the process of appointing or investing an appointee with the authority to perform a role or the legitimatized power to function in a role [22].

Limited knowledge on the part government officials.

The government officials perform with limited knowledge, use the laws to protect their weakness or deficiency and ignore the people. For example.

Section 18-(1) Government shall direct its policy towards ensuring that there are equal and adequate educational opportunities at all levels.

(2) Government shall promote science and technology

(3) Government shall strive to eradicate illiteracy and to this end Government shall

\section{'AS AND PRACTIABLE’ provide:}

- Free compulsory and universal primary education;

- Free secondary education

- Free university education and free adult literacy programme

\section{Comment}

The prospect of gaining adequate knowledge for all people of Nigeria was short changed and made elusive by the unqualified dead phrase-"as and when practicable". This implication is that As prevailing unfavourable conditions undermine the ability of Government to embark on the development of its citizens. Government then should and mount programmes to address these 'adverse' conditions at a target implement phases carry in the people until the final stage of accomplishment. These signals the expected time when-free education will be a right to any Nigerians (not a favour).

The disturbing fact is that the Government did not list these unfavourable conditions that sustain this dead phrase. The indifference on the part of the Government is understood and clear. It piles up huge 'idle' fund for the government. To abuse such fund will be a criminal abuse of public office. Major General Yakubu Gowon described the situation of huge idle fund thus:

The problem of Nigeria is not money but what to do with money. This depravity and short-sightedness on the part of the Military Head of State of Nigeria. 
Page 7 of 9

\section{Provision of a protected law of abuse}

The Government enacted a law or section of the constitution that gives it legitimate right to abuse public fund without any legal consequences:

Section 308- 'Immunity Clause'.

1. Notwithstanding anything to the contrary in this constitution but subject to subsection 2 of this section:

- No civil or criminal proceedings shall be instituted or continued against a person to whom this section applies during his tenure of office.

- A person to whom this section applies shall not be arrested or unprisoned during that period either in pursuance of the process of any court or otherwise and

1. The provisions of subsection (1) of this section shall not apply to civil proceedings against a person to whom this section in his official capacity or to civil or criminal proceedings in which such a person is only a nominal party.

2. This section applies to a person holding the office of President or Vice-President; Governor or Deputy Governor and the reference in this section to 'period of office' is a reference to the period during which the person holding such office is required to perform the functions of the office.

\section{Comment}

Section 308 gives thrust to protected corruption in high places because the person to whom this section acquires absolute discretion to manage the huge idle fund provided by section 18 (3c) of the 1999 CFRN anyhow without legal consequence or otherwise. See Table 2 for a disturbing gap in section 308. Section 308 ought to include a defined purpose: 'managing public fund for public prosperity only

\begin{tabular}{|c|c|c|c|}
\hline $\begin{array}{ll}\text { S308 } & 1999 \\
\text { CFRN } & \end{array}$ & Official Action & Purpose & Elite choice \\
\hline $\begin{array}{l}\text { President or } \\
\text { Vice-President } \\
\text { Governor or } \\
\text { Deputy } \\
\text { Governor }\end{array}$ & $\begin{array}{l}\text { Managing } \\
\text { Public Fund } \\
\text { anyhow }\end{array}$ & $\begin{array}{l}\text { Undefined, allowing } \\
\text { officials absolute } \\
\text { discretion in its } \\
\text { management }\end{array}$ & $\begin{array}{l}\text { Personal } \\
\text { Enrichment under } \\
\text { cover of protected } \\
\text { official action }\end{array}$ \\
\hline
\end{tabular}

Table 2: Disturbing Gap in Section 308 CFRN [17].

1. Section 308 protects the interests of elected politicians particularly the president or Vice-President; Governor or Deputy Governor. This section has no undefined dead phrase-like 'AS AND WHEN PRACTICABLE' in section 18 (3c) of the same constitution justifying incapacity or inability on the part of government to develop its citizens. This is democratized corruption. The ingenuity crafted in this section 308 CFRN [17] does not show a school certificate level intelligence and craftsmanship.

2. Democratized corruption in Nigeria: In developing countries corruption is equal to Monopoly and Discretion minus Accountability. The mathematical formular is:

$\mathrm{C}=\mathrm{M}+\mathrm{D}-\mathrm{A}$

Where $\mathrm{C}$ is corruption

$\mathrm{M}$ is Monopoly

\section{$\mathrm{D}$ is Discretion}

A is Accountability (Robert Wingaard in Professor C. Uche Department of Banking and Finances Universiyt of Nigeria Enugu Campus).

Section 308 has innovatively but negatively redefined the corruption formular for developing countries like Nigeria thus: mathematically: $\mathrm{C}=\mathrm{M}+\mathrm{Da}+1$

Where $\mathrm{C}$ is corruption

$\mathrm{M}$ is Monoploy

$\mathrm{Da}$ is absolute discretion

$1 \mathrm{c}$ is callous indifference

The nature of corruption in developing countries like Nigeria is a negative innovation. The word-'monopoly'- is not used in the economic sense like manufacturing. In most African States the 'stunted political context' is the monopoly. In Nigeria, it is the undeveloped character of our political history, inchoate political structure and system and mostly uninspiring cast of political leadership that threw Nigeria into regrettable but avoidable nderdevelopment which threatens its continuing existence. Also, the recklessness and impurity with which public institutions and resources are being handled, the daily news of systemic and now democratized corruption by political office holders and their business elite collaborators has turned politics into a monopoly [23]. The 'discretion' is callous. This is the order of events because the government deliberately reduces its citizens into mere population.

What is Law? Every government is the exact symbol of its people according to the Historian Thomas Carlyle so it is with law. The law and legal system of a society reflect the values of its people. In Nigeria section 308 CFRN [17] reflects the values of corruption and criminality.

The fairness of a nation's laws and the extent to which the legal system justly administers the law is a measure of the enlightenment, humanity and degree of civilization of its people. In Nigeria, the case of James Onanefe Ibori is hereby rendered as an illustration of this principle:

\section{Facts of the cases}

James Ibori former governor of Delta State and a stalwart of the ruling political party the People's Democratic Party PDP, is not new to controversies. Ibori, prior to the establishment of his newspaper, was like any other middle class Nigerian struggling to survive. By 1999 Ibori had stumbled into wealth (not earned by effort). But when he decided to go for a second term two lawyers ...filled an application in court to the effect that Ibori was an ex-convict. He was convicted by a Bwari Upper Area Court in 1995. Justice Hussein Baba Yusuf on March 24, 2003 ruled that Ibori was eligible to contest.

At the apex court, the justices ruled that "James Onanefe Ibori" was in actual fact convicted by the Bwari upper Area court for theft in 1995. Ibori was alleged to have stolen a bundle of zinc roofing sheet valued at $\mathrm{N} 110,000.00$

In 2007 EFCC took him to court over allegations of corruption while at the helm of affairs in Delta State, on December 17, 2009 a Federal High Court sitting at Asaba Delta State had given Ibori a clean bill of health in the case. Facts: The EFCC had alleged that Ibori used 
fronts and companies where he has interest to launder Delta State money to the tune of over $\$ 70$ million.

But Awokulehim in his ruling, declared that the EFCC did not have a water-tight case against Ibori and subsequently discharged and acquitted him on all the 170-count charges.

"Interpol arrested Ibori in Dubai and transferred his case to Britain where he is serving a prison term of over ten years. (Ikintunde Kazeem in [24]:10-11)" The difference is clear.

\section{National interest}

In most African states, perhaps, consequent on the fragility of their political structures, there is hardly any consensus on practically anything. Their language is more of comprise, judgement or inspiration. This situation should not surprise any astute observer of the African political scene. In the absence of institutionalized political structures, a different form of administration which settles issues more on political rather than insulated technical criteria of necessity takes the place of bureaucracy. Most of the African Governments are in reality, personal rulership, military dictatorships, or fragile democracies [25].

The negation of the representative principles and the enthronement of personal rulership in the Ivory Coast are illustrated by A.R. Bolberg as follows: it is in... the patter of decision-making that the P.D.C.I. in practice deviates most widely from the theoretical model of a party based on democratic centralism. Power resides almost exclusively in the hands of an individual...Felix Houphouet-Bioghy. Final decisions are... submitted to Houphouet-Boighy. During his many absences from the country, the work of government sometimes seems to come to a halt. Even routine decisions had to await his return. In Nigeria the same situation was replicated. President Umaru Yar'Adua admission in a Saudi hospital for more than two months now has been a source of national anxiety No one is happy that he has allowed his illness to create unnecessary constitutional crisis and tension in the Land.

\section{Declaration of asset}

He became the first Nigerian leader to publicly declare his assets and liabilities. His candour served notice that: after the UNSETTLING WHIRLWIND of Eight Years of OBASANJO's IMPERIAL PRESIDENCY ACCOUNTABLE TO NO ONE, Nigeria has arrived at the political equivalent of an Eldorado [26].

DEMOCRATIZED CORRUPTIONS and "As and WHEN PRACTIBLE"

"As and When practicable" is another name for corruption in Nigeria. The government inability to develop its people is caused by undefined dead phrase "As and When Practicable". Yet in Nigeria: "Little Wander that Nigeria's manufacturing is a mere $18 \%$ of our Gross Domestic Products compared to that of all those other nations with which we set off on the development race... Nigeria has had at least five cycles of commodity booms:

- The cycle of boom of the 2010 s

- The other four that happened in the 1970's ' 89 s, '90s and 2000s

- The squandering of the significant sum of $\$ 45$ billion in foreign reserve account and another

- $\$ 22$ billion in the Excess Crude Account
- Plus the addition of several hundred dollars realized from oil sale by the two administrations that have governed Nigeria in the last five years [23]

- Legislatives: How Federal Lawmakers squandered N700 billion [24]. A Nation's Unbearable Burden: The Nigeria National Assembly has become a drain through which the country is losing billions of Naira annually [27]

- Billions Down the Drain: How the poverty War failed in Nigeria [28]. The Failed Battle: The war on poverty in Nigeria has consumed billions of Naira but with little or nothing to show for the efforts [28].

- Gold Piggers in Government: How the political class Bleeds Nigeria [29] A Nation's Big Burden: Democracy in Nigeria has become a huge burden on the financial resources of the country and the political elite responsible for making it so do not seem to care [29].

Under this condition of personal rulership, military dictatorships or fragile democracies, principles are eliminated as an effective decision mode. The remaining modes are judgement and consensus. They require collegial and representative structures (not the federal character representation) in Nigeria. Inspite of the requirements of judgement and consensus, absolute responsibility for decision making is the exclusive right of the national leader. For example military Nigerian Leadership unilaterally created states in Nigeria. Also, Asaba became the headquater of Delta State of Nigeria because of the then first lady of Nigeria Mrs Mariam Babangida who is a native of Asaba. Warri an oil city like Portharcourt, capital of Rivers State of Nigeria, was relegated. The same military initiated the allocations of Nigeria's oil blocks to military heads of state of Nigeria for themselves, their inlaws and fronts [30].

The last of the four decision modes- 'Inspiration' and its corresponding anomic structure often strike some observes as mere heurisitics. Yet Uganda lives an epoc of inspiration decision-making. Field Marshall Idi-Amin Dada of Uganda for example, was never tired of explaining the relationship between his numerous dreams and some of his decisions in the performance of his leadership functions.

The laws from personal rulership or military dictator ship though binding on the illiterate and powerless people of Africa, are primitive and out of tune, with global demands. The real functions of law to be binding on enlightened citizens or population must be enacted a the strong institution constitutionally empowered to do so or there will anarchy. Law is the means through which society is able to exist by providing protection for the individual, by establishing and maintaining order, health and safety, by providing a peaceful means of dispute resolution, by providing stability and flexibility in economic relations between people and prohibiting conduct destructive of society [18].

A decree is an imposition and not a democratic law.

\section{Major findings}

1. The 1999 consitutions of the Federal Republic of Nigeria is Decree No 24 promulgated on 5th May 1999 by the Military Head of State of Nigeria. Its validity ought to expire with the exit of the regime that made it. The provisions in most parts do not promote the spirit of Nationalism among its people.

2. Section $18(3 \mathrm{c})$ prevents government from developing its people while section 308 empowers retired military generals to dominate the political terrain of Nigeria. 
3. The Federal territory in Abuja is a novelty of the military Heads of State of Nigeria. The novelty of federal territory was never contemplated for Lagos, the former capital Nigerian. This novelty provides opportunity for Federal Capital Territory Administration to compete with the Federal Government in Abuja.

4. There is a serious mistrust between the Nigerian government and its people resulting in a clean between them. The illiteracy of the people is a deliberate design in the constitutions to weaken its citizens and deny them clout to ask questions and even carry out a revolution.

\section{Conclusion}

Nigeria is an entrepreneurial reality of the British. The school certificate level requirement places many uniformed persons in government. The explosion of information through the internet and other media channels intimidate our unprepared politicians and render them as weak participants in global political and economic issues. Nigeria lacks strong institutions to guarantee enlightenment and development of its people through having political stability, good governance and example leadership. Forms of protection racket exist to undermine merit and technical qualification as well as encourage and sustain mediocrity. Nigerian nationalists are proven tribal champions. Tribalism is now a forceful factor through the entrenchment of the Federal character principle in chapter II section 14(3and) of CFRN [17]. Today, it is news when an applicant gets a job in any of our public organizations without knowing somebody. Even when the news is heard, it is received with unabashed incredibility. Nothing happens without necessary contacts [24]. This is the design of the military leaders to keep the populace blind through Decree 24 CFRN [17].

\section{Recommendations}

1. The 1999 constitution of the Federal Republic of Nigeria out lived its and usefulness and should be abolished to liberate Nigerians from mental enslavement and gain empowerment to form a democratic constitution that will consolidate the wishes, opinions and contributions of the people of Nigeria. This will turn us champions in Science and Technology and transform Nigerians as active participants in global politics and economics.

2. Making a good university degree from a recognized university the minimum qualification for the membership of the National Assembly will transform Nigeria's education system into being in the front burners of the national development of Nigeria as well as restore merit and technical qualifications in the recruitment of people with globally employable skill and make a ;productive global zone as well as Nigeria a global market.

\section{References}

1. Onah FE (2007) The impact of economic globalization on Nigeria's industrial sector, Nigerian Journal of social sciences Vol. 4. No. 1.

2. Colgan A (2002) Hazardous to health the World Bank and IMF in Africa Action (on-line).

3. Naomi C, Lewis P, Rothehild D, Stedman SJ (1999) Politics and society in contemporary Africa Oxford: Black Well Publishing Ltd.

4. Wallerstein I (1998) Utopistic or Historical New choices of the TwentyFirst Century New York: The New Press.
5. Moore LE (2005) Corporate community partnership what makes them work, why they fail Boston: Centres Publication.

6. Economic Commission for Europe (ECE) (2002) Best practice in Business Advisory, Counselling and information services New York: United Nations.

7. Enekwe OE (1989) Rich Land, Poor people' The Lagos Punch February 20; Taylor, Q (1990). The making of the modern world. A history of the twentieth centry, IOWA: Kendall Hunt Publishing Company.

8. Watts A (1969) Psychotherapy East and West 202 in Purvers JM, Farber WD, Tinsley JE, Bjorklund CC (1983) Business Law: Text and cases, New York: Harcourt Brace Inc and Ban Croft-Whitney Company.

9. Drucker PF (1979) The Practice of Management London: Richard Clay (The Chaucer Press) Ltd.

10. Federal Republic of Nigeria (2006) Obsanjo's Economic Direction 1999-2003, Ikeja: Dawn Functions Nigeria Limited.

11. World Bank, (2009:21).

12. Going East 2004.

13. Achebe C (2013) There was a Country, A personal History of Biafra London: Pengun Books Ltd 80 strand.

14. Oputa C (2004) Human Rights Violations Investigation Commission (HRVIC) Report in the NEWS (2004) A Report in the Cooler Vol.23 No 22 December 6.

15. Samuelson PA (1970) Economics, New York: McGraw-Hill Book Company.

16. Soludo CC (2008) Financial Globalization and Domestic Monetary Policy Whither the Economics for the 21st Century Nsukka: 40th Inaugural Lecture of the University of Nigeria, October 30th.

17. DECREE No 24: CONSTITUTIONS OF FEDERAL REPUBLIC OF NIGERIA ACT (1999).

18. Purver JM, Farber WD, Tinsley JE, Bjorklund CC (1983) Business LAW TEXT AND CASES, NEW YORK: Harcourt Brace Inc and Ban. CroftWhitney Company.

19. Perrew (1972) in Okoli F.C. (1999) Administration of National Development: Reflections on the Relevance of the Theory and Practice of Public Organizations to Developing Nations Nsukka: Tapmost Printing Press Production.

20. Geranty Hyden (1974) in Okoli F.C. (1999).

21. Gordon (1980) in Okoli, F.C. 1999.

22. Fatiregun EO (1992) Recruitment, selection and placement process. New Trends in Personnel Management. Badagang: Adeyemi Press Ltd IjebuIfe.

23. Ezekwesili O (2013) The wealth and Poverty of a nation, who shall restore the dignity of Nigeria? Being the 42nd convocation lecture delivered at the University of Nigeria Nsukka.

24. NEWSWATCH (2010) Ibori's Dubious Court Victories Vol. 51 No. 2 January 11.

25. Okoli FC (1999) Administration of National Development. Reflections on the Relevance of the Theory and Practice of Public Organizations to Developing Nations; Nsukka: Topmost Press Production.

26. NEWSWATCH (2010) Sick president, Divided Nation Vol. 51 No. 6 February 8.

27. NEWSWATCH (2010) Legislative How Federal Lawmakers Squandered 7 700Billion Vol. 52 No 2 July 12.

28. NEWSWATCH (2009) Billion Down the drain How the Poverty War Failed in Nigeria Vol. 50 No. 7 August 17.

29. NEWSWATCH (2011) GOLD Diggers in Govt How the Political Class Bleeds Nigeria vol. 53 No 26 June 27.

30. Alabo-George R (2012) Derivation and deprivation: Why the North is poor, Nigeria. 